\title{
TINDAKAN AFIRMATIF SEBAGAI BENTUK KEADILAN DALAM PEMBERIAN ASAS ULTIMATUM REMEDIUM DALAM UPAYA PENEGAKAN LINGKUNGAN AKIBAT ADANYA KEBAKARAN HUTAN
}

\author{
Ifahda Pratama Hapsari, \\ 1,2,3)Staf pengajar Hukum, Prodi Ilmu Hukum Universitas Muhammadiyah Gresik \\ *korespondensi: ifa.zegeeg@gmail.com
}

\begin{abstract}
ABSTRAK
.Upaya penegakan hukum lingkungan yang tegas merupakan salah satu cara untuk mencegah kelestarian lingkungan. instrumen hukum lingkungan dibuat dan ditegakan untuk mencegah terjadinya kerusakan lingkungan. namun, pada pelaksanaannya penegakan hukum lingkungan tidak senada dengan konsep pembangunan berkelanjutan. penegakan hukum lingkungan seolah hanya tajam kebawah namun tumpul keatas. dalam tulisan ini, akan dibahas penegakan hukum lingkungan di sektor kehutanan akibat terjadinya kebakaran hutan.dan kerusakan ekosistem didalamnya. pengelolaan hutan dan sumber daya alam yang berkelanjutan, karena pengelolaan hutan alam, hutan tanaman dan sumber daya alam yang ekstensif bersifat ekstratif telah menyebabkan terjadinya degradasi dan kerusakan demikian cepat. secara umum para pengelolaannya melakukan kegiatan eksploitasi terhadap sumber daya alam yang ada. kondisi itu dapat dilihat dengan adamya lokasi tambang yang tidak direklamasi, ileggal fishing illegal logging, pencemaran lingkungan, over loggin, kebakaran hutan yang membuat kualitas tanah semakin buruk yang dikarenakan adanya pengelolaan bersifat ekstratif tersebut, perbedaan sebab-akibat dalam kasus yang berbeda juga harus ditangani secara lebih complex lagi, karena adanya asas ultimatum remedium sebagai salah satu upaya terakhir dalam penegakan hukum. dan sebagai langkah upaya hukum terakhir untuk menindak pelaku kebakaran hutan. Kebakaran hutan itu sendiri tidak hanya sertamerta hanya melibatkan individu yang melakukannya, tetapi melibatkan juga Banyaknya perusahan selaku korporasi yang bertanggungjawab dalam halnya terjadinya kebakaran hutan. Tulisan ini akan mencoba menganalisis alasan pentingnya tindakan afirmatif bagi penegakan hukum lingkungan terutama hukum pidana.dalam hal pemberian sanksi ultimum Remedium sebagai upaya terakhir untuk menindak pelaku khususnya Korporasi sebagai pelaku utama kebakaran hutan.
\end{abstract}

Kata Kunci: Tindakan afirmatif, Asas Ultimum Remedium, Penegakan hukum Lingkungan, Kebakaran Hutan.

\section{PENDAHULUAN}

Negara Indonesia adalah Negara yang mendapatkan julukan Zamrud Katulistiwa yang bukan karena alasan negara yang terletak di persimpangan dua benua dan dua samudra serta berdiri kokoh diatas tiga lempeng tektonik dunia merupakan negara kepulauan terbesar didunia. Indonesia mempunyai garis pantai sepanjang 95.000 km2 dengan jumlah pulau sekitar 17.000 
buah. terumbu karang dalam jumlah besar tersebar diantara pulau-pulau ini. RRSEA (Reefs at Risk in Asia Tenggara) memperkirakan Indonesia mempunyai terumbu karang sekitar 51.000km2 ,jumlah ini, belum termasuk terumbu karang dalam jumlah besar yang belum terpetakan di wilayah terpencil. Dengan perkiraan terumbu karang seluas ini maka 51\% terumbu karang regional dan $18 \%$ terumbu

karang dunia terletak di Indonesia. selain 
luas, terumbu karang indonesia termasuk dalam kategori terkaya biodiveritasnya. didunia. saat ini lebih dari 480 spesies terumbu karang terdapat di Wilayah Timur Indonesia. Bahkan terumbu karang Indonesia menyokong perikanan dunia, menghasilkan 3,6 juta ton produksi ikan laut di tahun 1997. Selain laut yang kaya akan keakekaragaman hayati, daratan Indonesia pun daratan Indonesia pun terkenal dengan biodiveritasnya. hutan hujan tropis mempunyai keanekaragaan tanaman yang dapat disaingi oleh Amazon Hutan Hujan tropis di Indonesia menyimpan 105 dari Spesies tanaman-tanaman terkenal di dunia, lebih dari 25.000 spesies tanaman berbunga ditemukan di indonesia. di Kalimantan saja tercatat ada 2000 spesies anggrek yang tumbuh subur. sekitar $40 \%$ dari tumbuhtumbuhan ini tidak hidup di belahan dunia lain. Hutan Hujan Tropis Indonesia juga merupakan habitat bagi $12 \%$ spesies mamalia dunia termasuk terancam punah seperti Orangutan, Harimau sumatera dan Badak. Sumatra dan spesies burung di duniaIndonesia juga memiliki luas hutan bakau dunia. Data satelit terakhir menunjukan bahwa Indonesia mempunyai 3.1 juta hektar bakau atau 22.6\% dari bakau di dunia hutan ini penting untuk mitigasi perubahan iklim kepadatan karbon di hutan bakau lebih dari empat kali lebih tinggi daripada di hutan hujan tropis. di dataran tinggi.

Tanah air Indonesia juga kaya akan bahan tambang bernilai tinggi. Indonesia menduduki posisi ke 24 sebagai negara 
Produsen minyak mentah dunia dengan jumlah produksi 912.100 barel perhari. Tidak hanya minyak, Indonesia juga merupakan negara produsen gas alam. Kondisi alam yang amt sangat kaya ini merupakan harta karun bagi bangsa indonesia. kekayaan alam ini dapat dipergunakan sebesar-besarnya untuk kemakmuran bangsa indonesia sebagaimana yang diamanatkan dalam pasal 33 ayat (3) Undang-Undang Dasar 1945: "Bumi, Air, dan Kekayaan yang terkandung didalamnya dikuasai oleh negara dan dipergunakan untuk sebesar-besarnya kemakmuran rakyat". Pasal ini memiliki makna bahwa melarang adanya penguasaan sumber daya alam ditangan orang maupun seseorang. dengan kata lain, tidak dapat dibenarkan namun fakta lain, saat ini, berlaku didalam praktek-praktek usaha, bisnis dan investasi dalam bidang pengelolaan sumberdaya alam sedikit banyak bertentangan dengan prinsip pasal 33.

Kerusakan terumbu karang di indonesia terus meningkat setiap tahun. Berdasarkan data LIPI pada tahun 2011 menunjukan $30,76 \%$ terumbu karang memiliki kondisi yang kurang baik atau rusak. data yang dihimpun oleh 1076 stasiun pengamatan itu mengungkap hanya $5.58 \%$ karang dan kondisinya sangat baik, 26,59\% baik dan $36,90 \%$ sisanya cukup baik. kerusakan terumbu karamg Indonesia juga disebabkan oleh aktivitas daratan laju deforestasi yang tinggi kegiatan kehutanan dan perubahan peruntukan lahan telah meningkatkan jumlah endapan yang dibuang ke area 
terumbu karang, polusi dari limbah industri dan bahan penyubur mempengaruhi kondisi hanyati terumbu karang. Terumbu karang yang terkena dampak polusi menunjukan penurunan diversitas pada keadalaman 3Meter dan 40-160\% penurunan keanekaragaman hayati pada kedalaman 10 m. Perusakan lingkungan khususnya hutan yang disebabkan karena adanya kebakaran hutan disebabkan oleh karena kurang memperhatikan ekosistem. Pembentukan kawasan hutan sejatinya ditunjukan untuk menyediakan wilayah yang dikarenakan menjadi hutan tetap. Undang-Undang Nomor 41 Tahun 1999 tentang kehutanan (Undangundang Kehutanan menyebutkan bahwa status hukum kawasan hutan diperoleh melalui pengukuhan kawasan hutan yang terdiri atas tahapan penunjukan, penataan batas dan penetapan kawasan hutan.

Pada Tahun 2013 Kementrian Kehutanan melalui Peraturan Menteri Kehutanan (Permenhut) No. P.32/MenhutII/2013 tentang Rencana Makro Pemantapan Kawasan Hutan Menyebutkan bahwa luas kawasan Hutan baik yang terdapat didaratan maupun perairan adalah 130,68 juta hektar atau $68,4 \%$ dari luas wilayah daratan Indonesia kawasan dimaksud dibagi didalam berbagai macam fungsi yakni hutan konsenvasi seluas 26,82 juta hektar, hutan lindung seluas 28, 86 juta hektar, hutan produksi dengan luas 32,6 juta hektar, hutan produksi terbatas dengan luas 24,46 juta hektar dan hutan produksi yang dapat dikonversi seluas 17,94 juta hektar. yang kini sudah berkurang akibat adanya kebakaran 
hutan. Kebakaran Hutan terjadi karena adanya Proses Pembakaran secara Kimia dan fisika energi yang tersimpan dalam biomasaa dilepaskan pada saat bahan-bahan seperti daun, rumput, atau kayu berkombinasi dengan oksigen membentuk bahan-bahan seperti daun, rumput atau kayu berkombinasi dengan oksigen membentuk karbindioksida (Co2) air dan sejumlah substansi lain. indonesia itu sendiri memiliki sejumlah sanksi didalam Menerapkan aturan dalam usaha Penegakan hukum Lingkungan yang agar menghindarkan hukum tajam kebawah dan tumpul keatas yang melibatkan kalangan dalam kejahatan lingkungan koorporasi dalam skala besar.

Kerugian akibat kebakaran hutan dan lahan sangat besar sekali baik dalam kehidupan manusia maupun terhadap kehidupan makhluk hidup lainnya yang paling memperihatinkan adalah timbulnya korban akibat adanya keganasan api baik langsung maupun tidak langsung, serta hilangnya plasma nufah dan lenyapnya spesies tanaman dan binatang yang tidak mungkin kembali lagi. Dampak Kebakaran hutan akan sangat bergantung kepada bagaimana respon ekosistem terhadap adanya kebakaran yang dapat digambarkan melalui dampaknya terhadap sistem tanah, air, flora, fauna, atmosfir dan sosial masyarakat. secara garis besar dampak kebakaran yang terjadi secara umum meliputi asap yang mempengaruhi jarak pandang, yang menyebabkan pernapasan pada manusia terganggu, kualitas udara menurun, siklus hidrologi tanah terganggu, 
sehingga menyebabkan kekeringan pada musim kemarau, meningkatnya erosi tanah serta dapat menimbulkan kebakaran yang tidak terkendali.

Aturan pidana yang memiliki ancaman sanksi yang tinggi atau dikenal dengan Asas Ultimium remedium juga belum bisa memberikan hukuman yang menyeluruh kepada Pelaku Pembakaran Hutan Berdasarkan Latar belakang diatas, Maka Penulis tertarik untuk mengangkat judul Penelitian Tindakan Afirmatif sebagai bentuk keadilan dalam pemberian Asas Ultimum Remedium Dalam Upaya Penegakan Lingkungan Akibat Adanya Kebakaran Hutan. dengan Mengacu Kepada Permasalahan Tindakan Afirmatif apa saja yang dilakukan oleh Pemerintah didalam penerapan Sanksi Pidana guna Menegakan hukum lingkungan akibat adanya kebakaran hutan? dan untuk Permasalahan kedua akan berbicara dan mengkaji Bentuk Pertanggungjawaban Pidana Koorporasi terhadap adanya Tindak Pidana Kebakaran Hutan.

\section{METODE PENELITIAN}

Jenis penelitian yang digunakan adalah penelitian hukum normatif yaitu penelitian yang mengkaji peraturan perundangundangan yang mempunyai keterkaitan dengan obyek kajian penelitian khususnya mengenai asas-asas dan norma hukum yang tertuang dalam peraturan perundangundangan dan Dalam penelitian ini, metodependekatan yang digunakan adalah 
Approach) dan Pendekatan Konsep (ConseptualApproach).

Pendekatan Perundang-undangan (Statute

Approach), yaitu pendekatan dengan cara mengkaji dan menelaah peraturan perundang-undangan dan regulasi yang bersangkut paut dengan pokok permasalahan penelitian.

Pendekatan Konsep (Conseptual Approach), yaitu pendekatan dengan cara mempelajari pandangan dan doktrin dalam ilmu hukum, konsep, asas hukum yang relevan dengan pokok permasalahan penelitian

\section{HASILDAN PEMBAHASAN}

\section{Tindakan Afirmatif Sanksi Pidana (Ultimum \\ Remedium) dala}

\section{m Penegakan Kebakaran Hutan.}

Penanggulangan kejahatan dengan menggunakan (hukum) pidana merupakan cara yang paling tua, setua peradaban manusia itu sendiri. Pidana merupakan istilah yang lebih khusus dari "hukuman" yang menurut Sudarto bahwa "yang dimaksud dengan pidana ialah penderitaan yang sengaja dibebankan kepada orang yang melakukan perbuatan yang memenuhi syarat-syarat tertentu.Kata “ tindak pidana" merupakan terjemahan dari "straffbaar feit", Moeljatno memakai istilah "perbuatan pidana" oleh karena pengertian perbuatan lebih abstrak sehingga lebih luas dari pengertian tindak yang hanya menyatakan keadaan kongkrit,

Tirtaamidjaja memakai istilah "pelanggaran pidana" dan Utrecht memakai istilah "peristiwa pidana". Lebih 
lanjut dikatakan bahwa pada umumnya tindak pidana disinonimkan dengan delik, yang berasal dari bahasa latin yakni delictum. Dalam kamus besar bahasa Indonesia delik artinya perbuatan yang dapat dikenakan hukuman karena merupakan pelanggaran terhadap undangundang tindak pidana.Unsur-unsur yang terdapat dam pengertian diatas yaitu :

(1) Ada suatu perbuatan,

(2) Perbuatan itu dapat dikenakan hukuman, dan

(3) Perbuatan itu melanggar UndangUndang tindak pidana Definisi hukum pidana menurut Sudikno Mertokusumo yaitu:

"hukum pidana adalah hukum yang menentukan perbuatan-pebuatan apa atau siapa sajakah yang dapat dipidana serta sanksi-sanksi apa sajakah yang tersedia. Hukum pidanan dibagi menjadi hukum pidana materil dan hukum pidana formil. Hukum pidana materil ini membuat perbuatan-perbuatan melanggar hukum yang disebut delik dan yang diancam dengan sanksi. Hukum pidana formil atau hukum acara pidana mengatur bagaimana caranya negara menerapkan sanksi pidana pada peristiwa kongkrit Menurut Prodjohamidjojo bahwa: "hukum pidana ialah bagian dari keseluruhan hukum yang berlaku di suatu negara yang mengadakan dasar-dasar dan aturan-aturan untuk .Menentukan perbutan-perbuatan mana yang tidak boleh dilakukan. Sedangkan Menurut Schaffmeiter Perbuatan yang 
menyalahi apa yang telah diatur dalam ketentuan pidana tersebut adalah perbuatan yang melawan hukum. Schaffmeiter et. al, yang diterjemahkan oleh JE.Sahetapy membagi sifat melawan hukum menjadi empat makna yaitu :

a) sifat melawan hukum umum,

b) sifat melawan hukum khusus,

c) sifat melawan hukum formal dan

d) sifat melawan hukum materil. Sifat melawan hukum formal berarti :" semua bagian yang tertulis dari rumusan delik telah dipenuhi (jadi semua syarat tertulis untuk dapat dipidana), sedangkan sifat melawan hukum yang hendak dilindungi oleh pembentuk undang-undang dalam rumusan delik tertentu.

Hukum merupakan sarana perlindungan hutan, agar kelestarian kemampuan yang dimiliki oleh hutan dapat tetap terjaga. Oleh karena itu hukum harus ditegakkan. Menurut Mertokusumo

"Pelaksanaan hukum dapat berarti menjalankan hukum tanpa ada sengketa atau pelanggaran. Ini meliputi pelaksanaan hukum oleh setiap warga negara setiap hari yang tidak disadarinya dan juga aparat negara, seperti misalnya polisi yang berdiri di perempatan jalan mengatur lalu lintas (Law enforcement). Di samping itu pelaksanaan hukum dapat terjadi kalau ada sengketa, yaitu yang dilaksanakan oleh hakim. Ini sekaligus merupakan penegakanhukum".

Lebih lanjut
Mertokusumo mengatakan bahwa dalam menegakan hukum ada tiga unsur yang selalu harus diperhatikan, dalam penegakan hukum lingkungan dalam kaitannya dalam 
kebakran hutan. yaitu :kepastian hukum (rechticherheit), kemanfaatan (zweckmassigkeit) dan keadilan (gerechtigkeit). Kepastian hukum merupakan perlindungan yustisiabel terhadap tindakan sewenang-wenang yang berarti bahwa seseorang akan dapat memperoleh sesuatu yang diharapkan dalam keadaan tertentu. Fiat justitia et pereatmundus (meskipun dunia ini runtuh hukum harus ditegakan). Sebaliknya "masyarakat mengharapkan manfaat dalam pelaksanaan atau penegakan hukum. Demikian juga keadilan adalah hal yang harus diperhatikan dalam penegakan hukum yang harus dapat memberikan keadilan bagi masyarakat.

Penegakan hukum terhadap kejahatan di bidang kehutanan ini tidak lepas dari konsep penegakan hukum terhadap lingkungan. Hal ini merupakan konsekuensi logis bahwa hutan merupakan salah satu sektor lingkungan hidup. Penegakan hukum lingkungan di Indonesia mencakup penataan dan penindakan (complience and enforcement) yang meliputi bidang hukum administrasi negara, bidang perdata dan bidang hukum pidana. Fungsi sanksi pidana dalam kehidupan hukum lingkungan termasuk kehutanan telah berubah dari ultimatum remedium menjadi instrumen penegakan hukum yang bersifat premium remedium.
Lebih lanjut dinyatakan bahwa ketentuan tentang sanksi pidana dalam undangundang lingkungan hidup tentang tugas pemerintah menggariskan kebijakan dan melakukan tindakan yang mendorong ditingkatkannya upaya pelestarian lingkungan hidup yang serasi dan seimbang. Artinya, ada keseimbangan antara pemanfaatan maupun perlindungan terhadap hutan harus terintegrasi dalam satu konsep pembangunan. Dengan demikian perusak hutan perlu diberi penyuluhan, bimbingan serta insentif dandisinsentif, sehingga benar-benar menyadai kewajibannya dan bagi yang sengaja dan alpa mentaati ketentuan itu, dikenakan sanksi sebagai tindak lanjut.

Terkait sifat, dan fungsi dan tujuan hukum pidana masalah pengaturan sanksi pidana dalam peraturan perundangundangan dikenal dengan sebutan istilah "Ultimum Remedium dan Premium Remedium".

1. Makna Ultimum Remedium: "Bahwa sanksi pidana dipergunakan manakala sanksi-sanksi lainnya sudah tidak berdaya. Dengan perkataan lain dalam suatu undangundang sanksi dicantumkan sebagai sanksi yang terakhir, setelah sanksi perdata maupun sanksi administrasif".

2. Makna Primum Remedium: “ Dalam makna Primum Remedium ini, saksi Pidana dipergunakan sebagai senjata utama yang pertama kali diancamkan dalam suatu ketentuan undang-undang. sanksi hukum pidana yang tajam inilah 
yang membedakan dengan sanksisanksi dalam hukum-hukum yang lain. 
Pada prinsipnya, Penerapan hukum pidana merupakan upaya terakhir, akan terapi, perlu diperhatikan, bahwa prinsip Ultimum Remedium ini sebenarnya relevan digunakan pada tingkat legislasi.. Pada saat penyusunan undang-undang, para perumus undang-undang menggunakan prinsip ultimum remedium dalam menentukan perbuatan-perbuatan yang akan dikategorikan sebagai tindak pidana bukan sekedar pelanggaran administratif saja. Dengan mengacu kepada asas ultimum remedium tidak semua pelanggran akan dikriminalisasikan. apabila suatu perbuatan telah ditetapkan sebagai tindak pidana di dalam undang-undang, maka penegakan hukum pidana akan tindakan tersebut dapat dibenarkan.

Dalam Undang-undang No. 32 Tahun 3009 pendekatan hukum pidana bukan merupakan suatu upaya terakhir yang lazim disebut dengan ultimum remidium. dalam undang-undang 32 tahun 2009 ini ultimum remidium hanya berlaku untuk 1 (satu ) pasal saja yaitu pasal 100 Undang-undang 32 tahun 2009 yang menyatakan :

(1) setiap orang yang melanggar baku mutu air limbah, baku mutu emisi, atau baku mutu gangguan dipidana dengan pidana penjara paling lama 3 (tiga) tahun dan denda paling banyak Rp. 3.000.000.000,-.;

(2) tindak pidana sebagaimana dimaksud pada ayat (1) hanya dapat dikenakan apabila sanksi administrasi yang telah dijatuhkan tidak dipatuhi atau pelanggaran dilakukan lebih dari satu kali” 
Dari rumusan pasal diatas dapat diartikan bahwa:,"apabila sanksi administrasi tidak efektif atau pelanggaran dilakukan berulang, barulah sanksi pidana dijadikan tolak ukur didalam menindak kasus kebakaran hutan". Maka hal ini dapat di artikan bahwa: sanksi pidana berfungsi sebagai upaya terakhir.dalam kaitannya dengan Tindak Pidana Kebakaran Hutan yang marak terjadi akhir-akhir ini. Tindak pidana kebakaran hutan itu sendiri termasuk dalam kejahatan yang extraordinaryyang dimana disini, kejahatan nya itu sendiri diatur didalam Pasal 50 Undang-Undang N0 41 tahun 199 sedangkan untuk sanksi pidananya dirumuskan dalam Pasal 78. Dalam Pasal

78 terdapat 3 (tiga) jenis Pidana yaitu: Pidana Penjara, Pidana denda dan pidana Perampasan benda yang digunakan untuk melakukan perbuatan pidana dan ketiga jenis pidana ini dijatuhkan secara komulatif. adapun unsur-unsur untuk dapat dipidananya tindak pidana Kebakaran hutan sesuai Pasal 50 Undangundang No 41 tahun 1999 adalah:

ayat (1): Setiap orang dilarang merusak prasarana dan sarana perlindungan hutan. ayat (2):Setiap orang yang diberikan izin usah apemanfaatan kawasan,izin usaha pemanfaatan jasa lingkungan,izin usaha pemanfaatan hasil hutan kayu dan bukan kayu,serta izin pemungutan hasil hutan kayu dan bukan kayu,dilarang melakukan kegiatan yang menimbulkan kerusakan hutan

(3) Setiaporangdilarang: d. membakarhutan; 
Untuk Jenis sanksi Pidana yang berkaitan dengan Kebakaran itu sendiri diatur didalam Pasal 78 butir 3 yang berbunyi: Barang siapa yang melakukan dengan adanya unsur "Kesengajaan" sebagaimana dimaksud dalam Pasal 50 butir d diancam dengan Pidana penjara paling lama 15 (lima belas)tahun dan denda Paling banyakRp. 5000.000.000,00 (lima milyar rupiah) dan jika yang melakukannya Lalai hingga menyebabkan terjadinya kebakaran hutan, diancam dengan pidana 5 (lima) tahun dan denda paling banyak Rp 1.500.000.000,00 (Satu Milyar lima ratus juta rupiah.).

\section{Pertanggungjawaban Tindak Pidana}

\section{Koorporasi}

Hukum Pidana juga berlaku terhadap penjabat publik yang melakukan kesalahan yang dapat dipidana. Kesalahan dapat terjadi baikyang semata-mata karena kesalahan pribadi maupun perbuatan atau atau kelalaian dalam menjalankan jabtan. Dalam Negara yang berdasarkan hukum, penjabat dilarang melanggar perintah atau larangan yang berkaitan dengan jabatan. Hal tersebut sejalan dengan yang dinyatakan Petter bahwa: “

The Limittation of and control over the Powers of the states conctitue the real juridical dimension of criminal law the juridical task of criminal law is not policing socienty but poliching the police"(terjemahan bebas: Pembatasan dan pengawasan/pengendalian kekuasaan negara merupakan dimensi yuridis yang sesungguhnya dari hukum pidana. tugas yuridis dari hukum pidana bukan mengatur masyarakat tetapi mengatur penguasa.) 
Muladi dan Dwidja Priyatno menyatakan bahwa Koorporasi berasal dari kata "coorporate" yaitu suatu badan yang mempunyai sekumpulan anggota dan anggota-anggotamya tersebut mempunyai hak dan kewajiban sendiri yang terpisah dari hak dan kewajiban tiap-tiap anggota. Koorporasi merupakan sebutan yang lazim digunakan di kalangan ahli hukum pidana untuk untuk menyebut apa yang biasa dalam hukum lain khusunya dalam bidang hukum perdata, sebagai badan hukum atau dalam bahasa belanda disebut Recht Person dan dalam bahasa inggris disebut Legal Entities atau Corporation

Menurut Utrecht, Koorporasi juga diartikan sebagai "suatu gabungan orang yang dalam pergaulan hukum bertindak bersama-sama sebagai subyek hukum tersendiri atau suatu personifikasi". Koorporasi adalah badan hukum yang beranggotakan serta memiliki hak dan kewajiban terpisah dari hak dan kewajiban anggota masing-masing. JC Smith dan Brian Hogan mendefinisikan

Koorporasi sebagai:

"A Corporation is a legal person but it has no Pysical existence and cannot therefore, act or form an intetion of any kind except through it's directors or servants. As each director or servant is also a legal person quite distinct from the coorporation, it follows that a corporation's legal liabilities are all in a sense vicarius. this line of thinking is epitomized in the catchphrase "Coorporations don't commit crimes people do. (terjemahan: Koorporasi adalah badan hukum yang tidak memiliki fisik oleh karena itu, tidak dapat bertindak atau memiliki kehendak kecuali melalui direktor atau 
karyawannya. direktur atau karyawan juga merupakan entititas hukum yang berbeda dengan koorporasi, karena semua bentuk pertanggungjawaban hukum koorporasi adalah melalui pertanggungjawaban pengganti. pemikiran ini berarti bahwa koorporasi tidak bisa melakukan kejahtan tapi orang-orang yang bertindak untuk dan atau atas nama koorporsilah yang bisa melakukan kejahatan."

AZ Abidin mengemukakan secara etimologis Korporasi adalah "dipandang sebagai relita sekumpulan Manusia yang diberi hak sebagai unit oleh hukum yang diberikan pribadi hukum untuk tujuan tertentu".Terkait dengan pemikiran bahwa koorporasi tidak bisa melakukan tindakan hukum melalui orang-orang tertentu, Chidir ali menyatakan bahwa hukum memberi kemungkinan dengan memenuhi syaratsyarat tertentu, chidir ali menyatakan bahwa hukum memberi kemungkinan dengan memenuhi syarat-syarat tertentu, bahwa suatu perkumpulan atau badan lain dianggap sebagai orang yang merupakan pembawa hak dan karenanya, dapat menjalankan hak-hak seperti orang biasa serta dapat dipertanggunggugatkan. Namun demikian badan hukum (korporasi) bertindak harus dengan perantaraan orang biasa, akan tetapi orang yang bertindak itu tidak untuk dirinya sendiri, melainkan untuk dan atas pertanggungjawaban koorporasi.
Marshaal B. Clinard dan Peter C Yeager sebagaimana dikutip oleh Setiyono memberikan pengertian Kejahatan koorporasi sebagai "any act committed by corporation that is punished by the state, regardless of whether it is punished under administrative, civil, or criminal law" (setiap tindakan yang dilakukan dilakukan oleh koorporasi yang biasa diberi hukuman oleh negara entah dibawah hukum administrasi negara,hukum perdata, maupun hukum pidana.) .Sedangkan David O Friedrichs mendefinisikan Kejahatan koorporsi sebagai tindak pidana yang dilakukan oleh pengurus koorporasi untuk kepentinga koorporsi untuk kepentingan koorporasi atau tindak pidana yang dilakukan oleh koorporasi itu sendiri. (offences committed by corporate officials for their corporation or the offences of the corporation itself)

Niall F coburn secara lebih luas menjelaskan tentang dimensi yang terkait dengan Kejahtan Koorporasi sebagai berikut:

1. Penggelapan

2. Penipuan terhadap hasil audit internal dan pelanggaran terhadap kepatuhan kerja

3. Pelanggaran surat berharga termasuk perusahaan yang tidak menerapkan prinsip keterbukaan

4. Penyuapan

5. Penjualan Aset Perusahaan yang melibatkan orang dalam

6. Manipulasi Pasar 
7. Korupsi

8. Menghindari Kewajiban membayar pajak

9. Praktik-Praktik Perdagangan dan Perbuatan Pasar

10. Bisnis perusahaan pailit

11. Perhitungan laba perusahaan yang dipalsukan

12. Pembukuan Keuangan perusahaan yang tidak jujur

13. Penyelenggara perusahaan terkait dengan transaksi partai politik

14. Regulasi peraturan bersifat rahasia

15. Standar jalan raya dan kereta api

16. Tindak pidana ekonomi

17. Standar makanan

18. Praktik-Praktik diskriminatif saat ditempat kerja

19. pelanggaran terhadap aturan-aturan di bidang lingkungan kerja

20. Keamanan dan kesehatan Kerja

Alasan memasukan dan membatasi koorporasi sebagai badan hukum karena

memiliki unsur-unsur:

1. Mempunyai harta sendiri yang terpisah

2. Ada suatu organisai yang ditetapkan oleh suatu tujuan dimana kekayaan terpisah diperuntukan

3. Ada pengurus yang menguasai dan mengurusnya

Undang-undang No 32 Tahun 2009 tentang Perlindungan dan Pengelolan lingkungan hidup yang berkaitan dengan kebakaran hutan, dalam XV tentang ketentuan pidana, dijelaskan dalam Pasal 97 sampai Pasal 120 tentang jenis-jenis tindak pidana dan subyek
Pelaku tindak pidana lingkungan hidup.

Beberapa catatan yang terkait dengan tindak 
pidana di bidang lingkungan hidup

khususnya Pelaku koorporasi yaitu:

1. Tindak pidana lingkungan hidup merupakan tindak pidana Kejahatan (Pasal 97) hal ini, mengandung konsekuensi yuridis bahwa setiap orang "mencoba" atau "membantu" tindak pidana ini, juga diancam dengan Pidana.

2. Subyek hukumnya yaitu "setiap orang" yaitu: "Orang Perseorangan" dan/atau "Badan usaha" baik yang berbadan hukum maupun yang tidak berbadan hukum" (Pasal 1 angka 32). tampak bahwa yang dimaknai "Korporasi" disini: "Badan Usaha".

3. Ketentuan Pidana terhadap "badan usaha" diatur didalam Pasal 116, 117, 118 dan 119

a) Pasal 166 UU No. 32 Tahun 2009: apabila tindak pidana lingkungan hidup dilakukan oleh untuk atau atas nama badan usaha, tuntutan pidana dan sanksi pidana dijatuhkan kepada

1. Badan dan/atau

2. Orang yang memberi perintah untuk melakukan tindak pidana tersebuatau orang yang bertindak sebagai pemimpin dalam kegiatan dalam tindak pidana tersebut.

b) Terhadap tindak Pidana sebagaimana dimaksud dalam pasal 116 sanksi pidana dijatuhkan kepada badan usaha yang diwakili oleh pengurus yang berwenag mewakili didalam dan diluar pengadilan sesuai dengan peraturan perundang- undangan selaku pelaku fungsional.

Berdasarkan uraian diatas dapat diambil kesimpulan bahwa: 
1. Badan usaha dapat diminta pertanggungjawaban pidana manakala tindak pidana lingkungan hidup tersebut dilakukan oleh badan usaha untuk badan usaha atas nama badan usaha

2.Pertanggungjawaban pidana dijatuhkan kepada

a. Badan usaha

b. Orang yang memberi perintah atau orang yang bertindak sebagai pemimpin kegiatan dalam tindak pidana tersebut

c. Badan usaha atau orang yang memberi Perintah atau orang yang bertindak sebagai pemimpin kegiatan.

Sedangkan Pidana Tambahan diatur didalam Pasal 119 Undang-undang Lingkungan hidup:

1. Tidak dapat dijatuhkan secara mandiri artinya harus diikuti pidana pokok

2. Bersifat fakultatif (kebebasan bagi hakim untuk menjatuhkannya)

3. Harus diancamkan dalam pasalpasal terlebih dahulu.

Undang-undang Kehutanan itu sendiri yaitu undang-undang No 41 Tahun 1999 dikatakan bahwa "subyek" delik dalam undang-undang tersebut dibatasi pada orang perorangan. Undang-undang kehutanan pada dasarnya mengakui subyek delik tidak hanya orang perorangan tapi juga koorporasi dengan 2 (dua) alasan:

1. (1)Izin usaha pemanfaatan kawasan sebagai mana dimaksud dalam Pasal 26ayat(2) dapat diberikan kepada: "Perorangan" dan "Koperasi"
2. (2)Izin usaha pemanfaatan jasa lingkungan sebagaimana dimaksud dalam Pasal 26 ayat(2),dapat diberikan 
kepada:

"Perorangan

" "Koperasi", Badan Usaha milik Swasta Indonesia" dan "Badan Usaha Milik Daerah"

3. (3)Izin pemungutan hasil hutan bukan kayu sebagaimana dimaksud dalam Pasal 26 ayat

(2) "Perorangan" dan "Koperasi". Rumusan delik yang tercantum didalam Pasal

78 butir 14 Undangundang Kehutanan No 41 tahun 1999 (14)Tindak pidana sebagaimana dimaksud dalam Pasal

50ayat(1), ayat(2), dan ayat(3)apabila dilakukan oleh dan ata atas nama

badan hokum atau badan usaha,tuntutan dan sanksi pidananya dijatuhkan terhadap pengurusnya, baik sendirisendiri maupun bersamasama,dikenakan pidana sesuai dengan ancaman

pidana masing- masing ditambah dengan

1/3(sepertiga)dari pidana yang dijatuhkan.

Untuk mendukung dalil bahwa Koorporasi dapat dipertanggungjawabkan ada 2 Teori mengenai pertanggungjawaban Korporasi. yaitu "Doctrine Strict Liability" dan "Doctrine Vicarius Liability".

Doctrine Strict Liability:

Menurut Marise Cremona mendefinisikan Strict Liability sebagai: "The Phrase used to refer to criminal offeces Which do not Require mens rea in respect one or more element of the actus reus"(suatu ungkapan yang menunjuk kepada suatu perbuatan pidana dengan tidak mensyaratkan kesalahan terhadap satu atau lebih unsur actus reus).

Richard card berpendapat Strict Liability sebagai:" The accussed may be conviced although his conduct was meither intentional nor reckless nor negligent with references to the requisite consequence of the offence charge"(Terdakwa bisa saja dihukum meskipun perbuatannya bukan karena kesengajaan, kesemberonoan atau kealpaan berkenan dengan syarat yang diharuskan dalam suatu kejahatan yang dituduhkan. 
Pertanggungjawaban Doctrine Strict Liability disini adalah:

a Pertanggungjawaban pidana dapat dibebankan kepada pelaku tindak pidana yang bersangkutan dengan tidak perlu dibuktikan adanya kesalahan, kesengajaaan maupun adanya unsur kelalaian.

b. Doctrine ini juga disebut juga absolute liability oleh karena menurut ajaran ini pertanggungjawaban pidana bagi pelakunya tidak dipermasalahkan

c. Doctrine ini lebih dikenal dengan pertanggungjawaban Mutlak.

Doctrine Vicarius Liability:

Smith and Brian hogan menjelaskan:" a master can be held liable for his servant's crime as general rule two exeptions are in public nuicence and criminal libel, master has ben held liable for the servants act although he is personally, perfectly innocent (secara umum, majikan dapat dipertanggungjawabkan atas kejahatannyang dilakukan oleh pegawainya. kecuali terhadap gangguan umum dan fitnah atau pencemaran nama baik, maka majikan dipertanggungjawabkan atas tindakan pegawainya meskipun tidak bersalah sama sekali).

Menurut Henry Compbell: "Vicarius Liability is indirect legal responsibility, the liability of an employer for the acts of an employee or a principal for torts and contracts of an agent (Pertanggungjawaban pengganti adalah pertanggungjawaban hukum secara tidak langsung. pertanggungjawaban majikan atas tindakan dari pekerja atau pertanggungjawaban principal terhadap tindakan agen dalam suatu kontrak)"

Pertanggungjawaban Doctrine Vicarius Liability a. Pembebanan

Pertanggungjawaban pidana pidana dari tindak pidana yang dilakukan oleh orang lain

b. doctrine ini diambil dari hukum perdata dikenal dengan doctrine of resrespondeat superior

c. Terkait korporasi, dimungkinkan harus bertanggungjawab atas perbuatn-perbuatan yang dilakukan oleh para pegawainya, kuasanya atau mandatarisnya atau siapapun yng bertanggungjawab kepada korporasi tersebut

Sistem Pembenanan Pertanggungjawaban

Pidana Korporasi sebagaimana dimaksud oleh penulis disni adalah:

1. Hanya pengurus korporasilah yang bertanggungjawab terhadap tindak pidana

2. Korporasi yang melakukan tindak pidana tetapi Pengurus yang bertanggungjawab terhadap adanya tindak pidana tersebut

3. Korporasi sebagai pelaku tindak pidana dan Korporasi juga yang bertanggungjawab terhadap adanya tindak pidana

4. Pengurus dan Korporasi yang memikul tanggungjawab terhadap adanya tindak pidana yang ditimbulkannya. 


\section{KESIMPULAN}

1. Penerapan sanksi ultimum remedium dalam tindak pidana kebakaran hutan merupakan tindakan afirmatif untuk memberikan keadilan akibat adanya kebakaran hutan hanya dipergunakan manakala sanksi-sanksi lain sudah tidak berdaya. dengan perkataan lain, dalam suatu undang-undang sanksi pidana dicantumkan sebagai sanksi yang terakhir selain sanksi perdata dan sanksi administrasi penggunaan atau pemberian asas ultimum remedium didalam penegakan hukum juga harus memetingkan aspek -aspek keadilan baik bagi korban dan masyarakat yang dirugikan akibat adanya kebakaran hutan tersebut

2. Kesalahan korporasi, atau Tindak pidana lingkungan hidup yang berkaitan dengan Tindak pidana Kebakaran Hutan berdasarkan Pasal 78 ayat 14 yang untuk koorporasi ditambah dan diperberat 1/3 ini. sanksi ini diberlakukan tidak selalu ditimpakan kepada korporasi. ada 3 (tiga) kemungkinan dalam hal ini, yaitu: Pengurus saja yang bertanggungjawab, Korporai saja yang bertanggungjawab, serta Pengurus dan korporasi yang bertanggungjawab. ketiga hal ini disebut dengan Sistem Pertanggungjawaban Pidana Korporasi. dalam perundangundangan pidana diluar KUHP, sistem Pertanggungjawan pidana Korporasi tidak selamnya diakui. ada undang-undang pidana yang mengakui korporasi sebagai 
subyek delik dan membenahi tanggungjawab pidana atas tindak pidana yang dilakukannya, namun ada juga undang-undang pidana yang tidak mengakui korporasi sebagai subyek delik. Akibatnya, hanya orang -perorangan yang dibebani tanggungjawab pidana atas tindak pidana yang dilakukannya.

\section{SARAN}

1. Sebaiknya pemerintah dalam memberikan sanksi ultimum remedium diterapkan terakhir apabila sanksi perdata dan adminiatrasi sudah tidak mampu memberi solusi terhadap pelaku kebakran hutan

2. Diberlakukannya ancaman sanksi yang cukup tinggi didalam undang-undang tindak pidana Kehutanan terhadap korporasi yang melakukan tindak pidana sudah tepat. untuk memberikan keadilan dalam upaya penegakan hukum lingkungan karena adnya kebakaran hutan.

\section{DAFTAR PUSTAKA}

Abdurrahman, 1980, Aneka Masalah

Dalam Praktik

Penegakan Hukum di Indonesia, Alumni, Bandung

Didik Endro Purwolwksono,2019, Hukum Pidana Untaian Pemikiran, Penerbit Airlangga University Press, Surabaya 
G. Petter Hoefnagels, 1972, The Other

Side of Criminology-an

Inversion of the concept

of Crime Kluver-

Deventer, Holland

Hanafi Amrani dan Mahrus Ali, 2015, sistem

Pertanggungjawban

Pidana Perkembangan

dan Penerapan,

Rajawali Press, Jakarta

JE.Sahetapy, Hukum Pidana, Liberty,

Yogyakata , h. 39

Koeswadji,1993 Hukum Pidana

Lingkungan, Citra Aditya,

Bandung,

Leden Marpaung, 1991 Unsur-unsur

Perbuatan Yang Dapat

Dihukum, (Delik), Jakarta,

Sinar Grafika,

Marpaung, 1997 Tindak Pidana Lingkungan Hidup, Sinar Grafika, Jakarta,

Muladi dan Dwidja Priyatno,1991, Pertanggungjawaban Pidana Korporasi dalam Hukum Pidana, STIH, Bandung, h.19-20

Moeljatno, Asas-asas Hukum Pidana, CetakanKedua, Bina Aksara, Jakarta, 1984 ,

Peter Mahmud Marzuki, Perlunya

Undang-undang Tentang Macam dan Harga Mata Uang (penelitian) kerjasa sama dengan Bank Indonesia

Prodjohamidjoyo, 1997 Memahami Dasar-Dasar Hukum Pidana, Pradnya Paramita, Jakarta

Rangkuti, 2000 Hukum lingkungan

Dan Kebijakan
Lingkungan Nasional Airlangga

University, Surabaya, 
Sajipto Raharjo, 2009, Penegakan

Hukum : Suatu Tinjauan

Sosiologis, Genta

Publishing, Yogyakarta

Silalahi, 2001 Hukum Lingkungan

Dalam Penegakan

Hukum Lingkungan

Indonesia,

Alumni, Bandung,

Sudikno Mertokusumo, 1999

Mengenal Hukum Sebab

Pengantar, Liberty,

Yogyakarta,

Todung Mulya Lubis, dan

Alexander lay, 2009,

Kontroversi Hukuman

Mati

Perbedaan Pendapat,

Hakim

Konstitusi, Penerbit:

Buku Kompas,

Jakarta

\section{B. Peraturan Perundang-undangan}

a. UU No. 8 Tahun 1981 tentang Hukum Acara Pidana yang dundangkan dalam: (Lembaran Negara Tahun 1981 No. 9 Tambahan LN RI No.81)

b. UU No. 41 Tahun 1999 tentang kehutanan

c. UU No. 32 Tahun 2009 tentang Perlindungan dan Pengelolaan lingkungan hidup

d. UU No. 18 Tahun 2004 tentang Perkebunan

e. PP No. 4 Tahun 2001 tentang pengendalian Kerusakan dan pencemaran Lingkungan hidup yang berkaitan dengan kebakaran hutan dan lahan

\section{Internet}

1. Indonesia in Brief, http://www.undp.or.id/general/abo

ut_indonesia,asp, diakses tanggal 18 okt2019, jam 13.30

2.Reef at Risk in Indonesia, http://www.wri.org/publication/co $\underline{\text { ntet/8135, diakses tanggal } 18 \mathrm{okt}}$ 201914.00 
3. Indonesia's Rainforests:

Biodeversity and Engangered

Spesies,

http://ran.org./indonesia\%E2\%80\%9

9s-rainforests-biodeversity-and-

endangered-spesies diakses tanggal

18 Okt 2019 jam 20.05

4. Indonesia Perlu Memprioritaskan Hutan Bakau dalam mengatasi Perubahan iklim, http://reedindonesia.org/image/storiesdowload /indonesia_mangroves_Press_Relea se.pdf, diakses tanggal 18 Okt 2019 jam 21.00

5. The Word Factbook, http://www.cia.gov/library/publicati ons/the-world-

factbooks/rankorder/2241rank.html, diakses tanggal 18 Okt jam 21.15

6. Reef at Risk in Indonesia, http://www.wri.org/publication/contet $\underline{18135}$, diakses tanggal 21 okt 2019 12.50

D. Makalah Dan Jurnal

1. J. CIJRNS, Criminal Law as a Last Resort, electronic Journal of Comparative Law vol 13.4 DES 2001, http://www.ejcl.orgs

2. Rudi Prasetyo, 1989," Perkembangan Korporasi dalam Proses Modernisasi dan Penyimpanganpenyimpangannya" makalah disampaikan pada Seminar Nasional Kejahatan koorporasi FH, UDIP,23-24 Nov

3. Jurnal Hukum Lingkungan Vol 1 ISSUE 2 Des 2014, Indonesian Center for Environmental Law lembaga Pengembangan Hukum Lingkungan Indonesia. 